\title{
PENGARUH KETERLIBATAN KERJA TERHADAP KINERJA DENGAN PEMEDIASI KOMITMEN ORGANISASIONAL
}

\author{
Sebastianus Alexander Septiadi ${ }^{1}$ \\ Desak Ketut Sintaasih ${ }^{2}$ \\ I Made Artha Wibawa ${ }^{3}$
}

\author{
${ }^{1,2,3}$ Fakultas Ekonomi dan Bisnis Universitas Udayana (Unud), Bali, Indonesia \\ e-mail: bastianalextan@yahoo.com
}

\begin{abstract}
ABSTRAK
Penelitian ini mengkaji tentang pengaruh keterlibatan kerja terhadap komitmen organisasional dan kinerja. Penelitian ini melibatkan 135 orang responden yang semuanya merupakan pegawai Pusat Keuangan. dengan menggunakan sampel jenuh dengan mengambil seluruh pegawai untuk dijadikan responden. Skala Likert digunakan untuk mengambil skor penilaian kuesioner dan menggunakan uji validitas dan reliabilitas untuk pengujian kuesioner. Teknik analisis data yang dipergunakan adalah Structural Equation Model (SEM) menggunakan variance based dengan Partial Least Square (PLS) serta VAF untuk menguji variabel mediasi. Hasil dalam penelitian ini ditemukan bahwa keterlibatan kerja berpengaruh terhadap komitmen organisasional dan kinerja. Hasil penelitian ini mendukung teori bahwa semakin tinggi seseorang dilibatkan dalam suatu pekerjaan, maka semakin tinggi komitmen dan disiplin di dalam menjalankan tugasnya.
\end{abstract}

Kata Kunci : Keterlibatan Kerja. Komitmen Organisasional dan Kinerja Pegawai

\begin{abstract}
This study examined the effect of job involvement on job performance and organizational commitment as mediation. This study involved 135 respondents and using saturated sample which take all employee become a respondents. Likert Scale is used as a balanced assessment questionnaires and using validity and reliability for testing questionaires. The analysis tool in the research is Structural Equation Model (SEM) which using a variance-based approach with Partial Least Square (PLS) as well as to test the mediating variable VAF to testing. Result of study found that job involvement has a positive effect on organizational commitment and job performance at Defense of Ministry. Organizational commitment has positive influence on job performance at Pusat Keuangan and organizational commitment as Partial mediation proved directly affect the relationship between job involvement and job performance. can be given to the Defense of Ministry is increasing attention to the dimensions of salary, normative commitment, and discipline work as dimensions that have bad perception
\end{abstract}

Keywords : Job Involvement, Organizationl Commitment and Job Performance 


\section{PENDAHULUAN}

Menurunnya tingkat kinerja seseorang di dalam suatu organisasi disebabkan karena kurangnya karyawan yang dilibatkan di dalam suatu pekerjaan. Oleh karena itu, seharusnya organisasi lebih sering melibatan para pegawai dalam setiap pekerjaan, agar karyawan yang dilibatkan menjadi lebih berkomitmen dalam pekerjaan dan meningkatnya kinerja, dengan begitu dikatakan bahwa organisasi tersebut berhasil. Sethi (2016) menyatakan bahwa seseorang yang tidak terlibat berpartisipasi dalam organisasinya, maka akan menganggap bahwa pekerjaan dirasa tidak penting bagi harga diri serta tidak memiliki keterikatan secara emosional terhadap organisasi yang pada akhirnya berdampak negatif pada menurunnya kinerja. Selanjutnya (Nazish, 2013) menyatakan bahwa tingkat komitmen pegawai yang rendah di dalam organisasi, yang berakibat karyawan tidak memiliki keterikatan terhadap pekerjaan, serta kurang aktif dalam menyumbangkan ide-ide dan kontribusinya di dalam organisasi. Aditya (2014) mengungkapkan bahwa semakin rendahnya tingkat komitmen karyawan maka akan semakin rendah usaha karyawan dalam melakukan pekerjaan.

Pusat Keuangan Kementerian Pertahanan Republik Indonesia merupakan badan di bawah kementerian pertahanan yang bertanggung jawab atas pembiayaan dalam kegiatan pengelolaan dalam pembelian dan pengadaan (alutsista) alat utama sistem persenjataan. Karena itu, pegawai yang bekerja seharusnya sesuai dengan yang tercantum dalam visi terwujudnya pertahanan negara yang tangguh dan misi menjaga kedaulatan dan keutuhan wilayah negara 
kesatuan republik Indonesia serta keselamatan bangsa Pusat Keuangan Kementerian Pertahanan terletak di Jl. K.H. Wahid Hasyim No. 1 Jakarta Pusat Ching (2015) menyatakan bahwa keterlibatan kerja merupakan tingkat pekerjaan yang dialami karyawan yang mempengaruhi harga diri dan kinerja. Saxena (2015) menjelaskan bahwa keterlibatan kerja berkaitan dengan psikologi individu yang penting bagi citra individu. Keterlibatan kerja terkait karakteristik pribadi serta sifat dari tugas yang dapat meningkatkan faktor sosial seperti kerja tim, partisipasi pengambilan keputusan, seberapa besar karyawan mendukung tujuan organisasi, menujukkan prestasi serta kemajuannya dalam pekerjaanya (Bahram, 2010). Ketika karyawan diberikan peluang untuk berkontribusi melalui ide-ide dan saran dalam pengambilan sebuah keputusan, yang mana dapat meningkatnya kinerja yang karyawan dilibatan dalam membuat keputusan yang optimal yang dilihat sudut pandang yang beragam (kemelgor, 2002).

Albert (2015) mengemukakan bahwa Komitmen organisasional menyangkut rasa percaya serta penerimaan rasa yang kuat pada nilaiorganisasi, kemauan bekerja keras, dan menjaga keutuhan anggotanya. selain itu keinginan kuat dari anggota untuk bertahan pada organisasi dan memiliki ikatan psikologis. Menurut Goos (2002) mengklaim bahwa semua pekerjaan yang berhasil tergantung pada karyawan yang dilibatan di dalam suatu pekerjaan. Ekmekci (2011) berpendapat bahwa komitmen organisasi mengendalikan relasi antara organisasi dan individu serta mencoba untuk menjelaskan bagaimana individu telah terikat pada organisasi. 
Masalah yang terjadi di Kementerian Pertahanan di Pusat Keuangan dimana seharusnya pegawai yang dilibatkan dalam suatu pekerjaan sesuai dengan perintah tugas dari atasannya diharapkan seluruh pegawai ikut berpatisipatif secara aktif sesuai dengan kemampuan yang dimiliki agar dapat bekerja lebih berkomitmen serta meningkatkan kinerja. Tetapi pada kenyataanya, pegawai yang telah dilibatkan didalam suatu pekerjaan cenderung pegawai tidak berkomitmen dengan pada organisasi karena para pegawai yang bekerja tidak dengan kemampuan yang dimilikinya.

Wawancara yang dilakukan kepada Kepala Pusat Keuangan, Kepala bagian Tata Usaha, Kepala Bidang Pengendalian Administrasi Keuangan, Kepala Bidang Pelaksanaan Pembiayaan, Kepala Bidang Keuangan Kementerian, serta beberapa pegawai sebagai sampel di Pusat Keuangan, berdasarkan hasil wawancara maka dapat disimpulkan bahwa, pengurangan pegawai tersebut dinilai lebih efektif jika pegawai yang bekerja akan lebih memiliki komitmen dan tanggung jawab yang tinggi dalam bekerja.

Tabel 1

Penilaian Pegawai Berdasarkan Keterlibatan Kerja

\begin{tabular}{|c|c|c|c|c|c|}
\hline \multirow[b]{2}{*}{ No } & \multirow[b]{2}{*}{ Aspek Penilaian } & \multicolumn{4}{|c|}{ Jumlah Pegawai (Orang) } \\
\hline & & $\begin{array}{c}\text { Sangat } \\
\text { Tinggi }\end{array}$ & Tinggi & Cukup & Rendah \\
\hline 1 & Berpartisipasi dalam Pekerjaan & 1 & 2 & 2 & 5 \\
\hline 2 & Mengutamakan Pekerjaan & 1 & 1 & 1 & 7 \\
\hline 3 & Pekerjaan penting bagi harga diri & 2 & 1 & 2 & 5 \\
\hline 4 & Handal menyelesaikan pekerjaan & 2 & 2 & 2 & 4 \\
\hline 5 & Mengevaluasi Pekerjaan & 3 & 1 & 2 & 4 \\
\hline 6 & Fokus dalam Pekerjaan & 1 & 2 & 2 & 5 \\
\hline
\end{tabular}

Hasil wawancara menunjukkan bahwa dari 6 aspek penilaian pegawai berdasarkan keterlibatan kerja di Pusat Keuangan berdasarkan hasil wawancara dengan mengambil sampel 10 orang pegawai maka terdapat 7 orang pegawai yang 
memiliki keterlibatan rendah dari aspek mengutamakan pekerjaan dan 3 orang pegawai yang memiliki keterlibatan tinggi dari aspek mengevaluasi pekerjaan.

Tabel 2

Penilaian Pegawai Berdasarkan Komitmen Organiasional

\begin{tabular}{llcccc}
\hline \multirow{2}{*}{ No } & \multicolumn{1}{c}{ Aspek Penilaian } & \multicolumn{3}{c}{ Jumlah Pegawai (Orang) } \\
& & $\begin{array}{c}\text { Sangat } \\
\text { Tinggi }\end{array}$ & Tinggi & Cukup & Rendah \\
\hline 1 & Menghabiskan karir di Pusku & 5 & 2 & 2 & 1 \\
2 & Bangga menjadi bagian dari Pusku & 6 & 2 & 1 & 1 \\
3 & Pekerjaan penting bagi harga diri & 2 & 2 & 2 & 4 \\
4 & Berat meninggalkan Pusku & 3 & 2 & 3 & 2 \\
5 & Lingkungan kerja yang mendukung & 1 & 1 & 2 & 6 \\
6 & Kebebasan dalam Pekerjaan & 1 & 1 & 2 & 6 \\
\hline
\end{tabular}

Sumber : Pusat Keuangan Kementerian Pertahanan 2015

Hasil wawancara menunjukkan bahwa dari 6 aspek penilaian pegawai berdasarkan komitmen organisasional di Pusat Keuangan berdasarkan hasil wawancara dengan mengambil 10 orang pegawai maka terdapat 6 orang pegawai dengan komitmen sangat tinggi dilihat dari aspek penilaian bangga menjadi bagian dari Pusat Keuangan dan 6 orang pegawai dengan komitmen rendah yang dilihat dari aspek penilaian lingkungan kerja yang mendukung dan kebebasan dalam pekerjaan.

Tabel 3

Penilaian Pegawai Berdasarkan Penilaian Umum

\begin{tabular}{clcccc}
\hline \multirow{2}{*}{ No } & & \multicolumn{3}{c}{ Jumlah Pegawai (Orang) } \\
& & $\begin{array}{c}\text { Baik } \\
\text { Sekali }\end{array}$ & Baik & Cukup & Kurang \\
\hline 1 & Moral & 3 & 20 & 72 & 40 \\
2 & Disiplin & 4 & 15 & 99 & 17 \\
3 & Dedikasi & 5 & 40 & 78 & 12 \\
4 & Kejujuran & 18 & 35 & 74 & 8 \\
5 & Tanggung Jawab & 27 & 32 & 51 & 25 \\
6 & Keuletan & 14 & 27 & 76 & 18 \\
7 & Kesetabilan Jiwa & 8 & 16 & 97 & 14 \\
8 & Loyalitas & 11 & 21 & 35 & 68 \\
9 & Penyesuaian Diri & 16 & 38 & 28 & 53 \\
10 & Kemauan Untuk Maju & 12 & 18 & 80 & 25 \\
\hline Sumber : Laporan Penilaian Pegawai Pusat Keuangan Kementerian Pertahanan &
\end{tabular}


Hasil wawancara menunjukkan bahwa penilaian umum pegawai Pusat Keuangan 27 orang pegawai yang memililkit tanggung jawab baik sekali dan 68 orang pegawai yang memiliki loyalitas yang kurang. Penilaian ini dilakukan secara priodik per Triwulan (TW.I, TW.II, TW.III dan TW.IV) didalam satu tahun anggaran berjalan (TA. 2016) dan kegiatan tersebut dilakukan secara rutinitas setiap tahunnya, dengan kata lain secara berulang dan dilaksanakan pengkajian pada kegiatan yang sudah terlaksana agar dapat dijadikan bahan evaluasi dan proyeksi kedepan.

Rumusan masalah sesuai dengan latar belakang diatas dapat dirumuskan berikut: 1). Apakah keterlibatan kerja berpengaruh terhadap komitmen organisasional di Pusat Keuangan Kementerian Pertahanan? 2). Apakah keterlibatan kerja berpengaruh terhadap kinerja pegawai Pusat Keuangan Kementerian Pertahanan? 3). Apakah komitmen organisasional berpengaruh terhadap kinerja pegawai Pusat Keuangan Kementerian Pertahanan? 4). Apakah komitmen organisasional memediasi pengaruh keterlibatan kerja terhadap kinerja pegawai di Pusat Keuangan Kementerian Pertahanan?

Tujuan penelitian sesuai berdasarkan rumusan masalah antara lain: 1). Untuk menganalisis pengaruh keterlibatan kerja terhadap komitmen organisasional di Pusat Keuangan Kementerian Pertahanan. 2). Untuk menganalisis pengaruh keterlibatan kerja terhadap kinerja pegawai di Pusat Keuangan Kementerian Pertahanan. 3). Untuk menganalisis pengaruh komitmen organisasional terhadap kinerja pegawai di Pusat Keuangan Kementerian Pertahanan. 4). Untuk menganalisis pengaruh komitmen organisastional memediasi pengaruh 
keterlibatan kerja terhadap kinerja pegawai di Pusat Keuangan Kementerian Pertahanan

Robbins \& Coulter (2012:377) menyatakan bahwa keterlibatan kerja merupakan tingkat identifikasi karyawan terhadap pekerjaannya, secara aktif berpartisipasi dalam pekerjaanya, dan menganggap kinerja dalam pekerjaaannya lebih berharga untuk kebaikan diri sendiri. Istijanto (2005) menyatakan bahwa ada 6 indikator yang dapat digunakan dalam mengukur tinggi tinggi rendahnya keterlibatan kerja sebagai berikut: 1). Aktif berpartisipasi dalam pekerjaan Aktif berpartisipasi dalam pekerjaan menunjukkan keikutsertaan dan perhatian terhadap pekerjaan. 2). Menunjukkan pekerjaan adalah yang utama Individu yang mengutamakan pekerjaan akan terus berusaha yang terbaik demi pekerjaannya dan merasa bahwa pekerjaan sebagai sesuatu yang menarik dalam kehidupannya serta layak diprioritaskan.

3). Melihat pekerjaan sebagai sesuatu yang penting bagi harga diri Keterlibatan kerja dapat dilihat dari perilaku seseorang mengenai pekerjaannya, dimana seseorang menganggap pekerjaan penting bagi harga diri. 4). Keterlibatan mental dan emosional Keterlibatan tidak selalu terkait kegiatan fisik tetapi dapat berupa mental dan emosional. 5). Motivasi Kontribusi Keterlibatan dimana keadaan manajer memotivasi orang- orang untuk memberikan distribusi. 6). Tanggung Jawab Keterlibatan mendorong orang-orang untuk menerima tanggung jawab dalam aktivitas kelompok

Griffin (2004:60) menyatakan bahwa komitmen organisasional merupakan perilaku yang menunjukkan seberapa jauh seseorang mengenal serta terikat dalam 
organisasi. Menurut Noe (2011:308) komitmen organisasi adalah sejauh mana seseorang mengidentifikasi organisasi dan bersedia untuk mengajukan upaya atas namanya. Seseorang dengan komitmen yang tinggi kemungkinan maka menganggap dirinya sebagai anggota yang setia pada organisasi. Tiga komponen menurut Allen dan Meyer (2007) yang untuk mengukur komitmen organisasional : 1). Komitmen afektif (Affective Commitment) $\left(\mathrm{M}_{1}\right)$. adanya rasa untuk terikat pada organisasi. 2). Komitmen berkelanjutan (Continuance Commitment) $\left(\mathrm{M}_{2}\right)$. Komitmen yang didasarkan pada kebutuhan primer. 3). Komitmen normatif (Normative Commitment) $\left(\mathrm{M}_{3}\right)$. Komitmen yang didasarkan pada norma-norma dalam diri karyawan, keyakinan seseorang terhadap tanggung jawab organisasinya.

Menurut Wibowo (2010:7) mengemukakan bahwa kinerja adalah proses dalam melakukan pekerjaan hingga mencapai hasil yang diraih dari suatu pekerjaan. Selain itu kinerja didukung oleh. Sedarmayanti (2011:260) mengungkapkan bahwa Kinerja merupakan hasil kerja seorang dalam pekerja, proses kegiatan yang melibatkan seluruh anggota organisasi, yang mana hasil kerja harus dapat dibuktkan secara nyata, dapat diukur (dibandingkan pada standar yang ditetapkan).

Jackson dan Schuler (2011) dan berdasarkan ketetntuan pelaksanaan peraturan pemerintah nomor 46 tahun 2011 dan kepala badan kepegawaian negara nomor 1 tahun 2013 tentang penilaian kinerja untuk mengukur kinerja dibagi menjadi dua yaitu: 1). Kinerja berdasarkan prilaku (behavior criteria) Fokus dengan pelakasanakan pekerjaan, perilaku dalam malakukan pekerjaan 
berdasarkan tugas dan tanggung jawab, seperti ketidakhadiran, keterlambatan, kecerobohan, kerja sama, prakarsa. 2). Kinerja berdasarkan hasil (result criteria) Fokus pada yang diselesaikan atau dihasilkan daripada bagaimana pekerjaan yang diselesaikan atau dihasilkan, seperti kuantitas, kualitas, waktu.

Agheli (2015) mengemukakan bahwa meningkatnya keterlibatan kerja dari karyawan maka komitmen organisasional juga akan meningkat serta kecenderungan karyawan untuk berhenti dari pekerjaanya juga akan menurun jadi terdapat hubungan positf antara keterlibatan kerja dan komitmen organisasional. Berdasarkan penelitian yang dilakukan Khanam (2015) menyatakan bahwa terdapat hubungan positif antara keterlibatan kerja dan komitmen organisasional. Manajemen organisasi harus mengembangkan partisipasi yang sama kepada karyawan dalam pengambilan keputusan sehingga karyawan dan berkomitmen dengan organisasi mereka. Rizwan (2015) mengatakan bahwa terdapat hubungan yang positif kertelibatan kerja terhadap kinerja karyawan Jika karyawan yang akan dilibatkan dalam pekerjaannya, maka kinerjanya akan lebih baik untuk kinerja organisasinya secara keseluruhan di organisasi tempat bekerjanya. Oleh karena itu keterlibatan kerja tinggi akan meningkatkan komitmen organisasi juga kinerja karyawan. Hubungan yang positif pada keterlibatan kerja dan komitmen organisasional lebih menekankan pada dimensi komitmen afektif (Khan, 2012). 


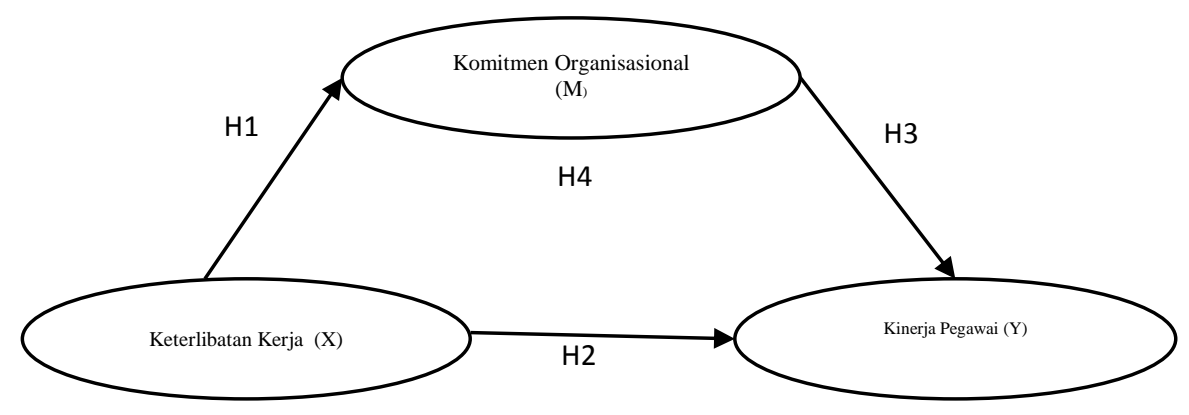

Gambar 1. Kerangka Berfikir Konseptual

Sumber:

H1: Agheli (2015), Khanam (2015), Rizwan (2015), Khan (2012), Majid (2015), Hannah (2013)

H2: Khan (2011), Jayarathna (2014), Aisha (2014), Rizwan (2011), Greis (2011) Roselina (2013)

H3: Memari (2013), Anan (2015), Ziauddin (2010), Mehdieh (2013), Preeti (2014) Erkut (2014)

H4: Ekmekçi (2011), Chungtai (2008), Kenny (1986), Armanu (2015), Akram (2014)

Penelitian yang dilakukan Agheli (2015) menyatakan bahwa adanya hubungan positif antara keterlibatan kerja dan komitmen organisasional. Khanam (2013) mengungkapkan adanya hubungan keterlibatan kerja positif dan signifikan terhadap kinerja. Rizwan menjelaskan bahwa keterlibatan kerja berpengaruh positif signifikan terhadap komitmen organisasional. Khan (2012) menjelaskan bahwa keterlibatan kerja berpengaruh positif terhadap komitmen organisasional. Majid (2015) mengatakan bahwa keterlibatan kerja berpengaruh positif terhadap komitmen organisasional. Hannah (2013) menunjukkan bahwa keterlibatan kerja berpengaruh positif terhadap komitmen organisasional.

$\mathrm{H}_{1}$ : Keterlibatan Kerja berpengaruh positif dan signifikan terhadap Komitmen Organisasional

Penelitian yang dilakukan oleh Khan (2011) menunjukkan bahwa keterlibatan kerja berpengaruh positif signifikan terhadap kinerja. Aisha (2014) 
menyatakan keterlibatan kerja karyawan berhubungan positif dengan kinerja karyawan. Rizwan (2011) mengemukakan jadi adanya hubungan positif keterlibatan kerja dengan kinerja. Greis (2015) mengemukakan bahwa keterlibatan kerja berpengaruh positif dan sigifikan terhadap kinerja. Roselina (2013) menyatakan bahwa adanya hubungan antara keterlibatan kerja terhadap komiten efektif. Jayarathna (2014) mengungkapkan bahwa keterlibatan kerja berpengaruh positif dan signifikan terhadap komitmen organisasional.

$\mathrm{H}_{2}$ : Keterlibatan Kerja berpengaruh Positif dan signifikan terhadap Kinerja Penelitian yang dilakukan (Memari, 2013) menuatakan bahwa komitmen organisasional berpengaruh secara signifikan dan positif terhadap kinerja karyawan. Adnan (2015) mengemukakan bahwa komitmen organisasional berpengaruh positif dan signifikan terhadap kinjerja. Ziauddin (2010) mengungkapkan bahwa komitmen organisasional memiliki hubungan positif dan signifikan terhadap kinerja. Mahdieh (2013) menjelaskan bahwa adanya hubungan positif signifikan antara komitmen organisasional dan kinerja. Preeti (2014) menemukan adanya hubungan positif dan signifikan komitmen organisasional terhadap kinerja. Erkut (2014) menjelaskan bahwa komitmen organisasional berpengaruh positif dan signifikan terhadap kinerja.

$\mathrm{H}_{3}$ : Komitmen Organisasional berpengaruh positif dan signifikan terhadap Kinerja Pegawai

Penelitian yang dilakukan Ekmekçi (2011) membuktikan bahwa keterlibatan kerja berpengaruh positif terhadap kinerja melalui komitmen organisasional. Chungtai (2008) menyatakan bahwa keterlibatan kerja berpengaruh postif terhadap kinerja dan komitmen organisasional sebagai 
pemediasi secara parsial. Kenny (2011) mengungkapkan adanya pengaruh keterlibatan kerja dan terhadap kinerja karyawan terhadap yang di mediasi secara parsial terhadap komitmen organisasional sebagai variabel mediator. Armanu (2015) menjelaskan bahwa keterlibatan kerja berpengaruh terhadap kinerja pegawai yang dimediasi secara parsial oleh komitmen organisasional. Akram (2014) menyatakan bahwa terdapat hubungan positif antara keterlibatan kerja terhadap kinerja karyawan yang di mediasi parsial oleh komitmen organisasional

$\mathrm{H}_{4}$ : Keterlibatan Kerja berpengaruh terhadap Kinerja berpengaruh Positif dan Signifikan yang dimediasi oleh komitmen organisasional

\section{METODE PENELITIAN}

Rancangan penelitian merupakan suatu rencana yang terstruktur dan komprehensif mengenai hubungan-hubungan antar variabel-variabel yang disusun sedemikian rupa agar hasil risetnya dapat memberikan jawaban atas pertanyaan-pertanyaan riset. Rancangan penelitian merupakan suatu rencana yang terstruktur dan komprehensif mengenai hubungan-hubungan antar variabelvariabel yang disusun sedemikian rupa agar hasil risetnya dapat memberikan jawaban atas pertanyaan-pertanyaan riset. Rancangan penelitian ini bersifat (explanatory research) dalam menjelaskan suatu hubungan antara variablevariabel melalui pengujian hipotesis

Ruang lingkup penelitian ini mengambil tempat di Pusat Keuangan Kementrian Pertahanan, agar dapat mengetahui pengaruh keterlibatan kerja terhadap komitmen organisasional dan kinerja pegawai. Dari hipotesis yang telah disusun, maka dapat ditentukan variabel penelitian. Penelitian ini yang menjadi variabel bebas adalah keterlibatan kerja, variabel terikat adalah komitmen 
organisasi dan kinerja pegawai. Setelah penetapan sampel, maka akan dilanjutkan dengan pengumpulan data melalui metode observasi, wawancara dan penyebaran kuesioner kepada responden.

\section{Definisi Operasional Variabel}

Keterlibatan kerja (X) merupakan bentuk perilaku karyawan yang memiliki komitmen yang tinggi dalam melaksanakan tugas dan tanggung jawab dimana tempatya bekerja serta memiliki rasa memiliki, kepercayaan dan dukungan yang berdampak meningkatkanya kepuasan individu dan meningkatnya kinerja dalam organisasi. Indikator yang digunakan untuk mengukur keterlibatan kerja indikator sebagai berikut: a). Aktif berpartisipasi dalam pekerjaan $\left.\left(\mathrm{X}_{1}\right), \mathrm{b}\right)$. Menunjukkan pekerjaan adalah yang utama $\left(\mathrm{X}_{2}\right)$. c). Melihat pekerjaan sebagai sesuatu yang penting bagi harga diri $\left(\mathrm{X}_{3}\right)$. d). Keterlibatan mental dan emosional $\left(\mathrm{X}_{4}\right)$. e). Motivasi Kontribusi $\left(\mathrm{X}_{5}\right)$. f). Tanggung Jawab $\left(\mathrm{X}_{6}\right)$

Komitmen Organisasional (M) kepercayaan dan penerimaan yang kuat terhadap nilai-nilai organisasi, kemauan untuk bekerja keras dalam memelihara keanggotannya dalam organisasi yang bersangkutan, yang berarti ada keinginan yang kuat dari anggota untuk tetap berada dalam organisasi serta adanya ikatan psikologis terhadap organisasinya. ada tiga komponen menurut Allen dan Meyer (2007) yang untuk mengukur komitmen organisasional : 1). Komitmen afektif (Affective Commitment) $\left(\mathrm{M}_{1}\right)$. 2). Komitmen berkelanjutan (Continuance Commitment) $\left.\left(\mathrm{M}_{2}\right) .3\right)$. Komitmen normatif (Normative Commitment) $\left(\mathrm{M}_{3}\right)$

Kinerja Pegawai (Y) hasil pekerjaan yang diperoleh seseorang di dalam melaksanakan tugas yang dibebankan sesuai dengan tanggung jawab yang 
diberikan. penilaian kinerja untuk mengukur kinerja dibagi menjadi dua yaitu : Kinerja berdasarkan prilaku ( behavior criteria ) ( $\left.\mathrm{Y}_{1}\right)$ Kinerja berdasarkan hasil (result criteria) $\left(\mathrm{Y}_{2}\right)$

Metode penlitian ini adalah asosiatif yang menggunakan 1(satu) variabel bebas, 1(satu) variabel mediasi dan 1(satu) variabel terikat. Variabel yang digunakan dalam penelitian ini adalah variabel terikat (dependent) yaitu kinerja pegawai, variabel bebas (independent) yaitu keterlibatan kerja dan variabel mediasi yaitu komitmen organisasional. Jumlah populasi sampel yang diambil 135 (serratus tiga puluh lima) orang. Sampel yang diambil menggunakan sampel jenuh penentuan sampel bila seluruh anggota populasi dijadikan sebagai sampel.

Teknik analisis data yang digunakan pada penelitian ini adalah Partial Least Square (PLS) untuk mengetahui kompleksitas hubungan suatu konstrak dan konstrak yang lain, serta hubungan konstrak dan indikator-indikatornya.

Jenis Data

Data Kualitatif data dalam penelitian ini adalah lokasi penelitian, karakteristik responden, yang meliputi jenis kelamin, usia, pendidikan terakhir, pendapatan, instrument penelitian.

Data kuantitatif dalam penelitian ini adalah jumlah pegawai Pusat Keuangan Kementerian Pertahanan.

Populasi dan Sampel

Populasi dalam penelitian ini adalah pegawai di Pusat Keuangan Kementerian Pertahanan baik PNS (Pegawai Negeri Sipil dan Militer) Data jumlah pegawai pusat keuangan kementrian pertahanan yang berjumlah 135 
orang yang terdiri dari 109 orang pegawai negeri sipil (PNS) dan 26 orang pegawai Militer.

Tabel 4

Jumlah Sampel Pegawai Pusat Keuangan

\begin{tabular}{|c|c|c|}
\hline No & Satuan Kerja & Jumlah Populasi \\
\hline 1 & Tata Usaha & 41 \\
\hline 2 & Pengendalian dan Administrasi Keuangan & 22 \\
\hline 3 & Pelaksanaan Pembiayaan & 19 \\
\hline 4 & Keuangan Kementrian & 49 \\
\hline 5 & Analis Madya & 2 \\
\hline \multirow[t]{2}{*}{6} & Luar Formasi & 2 \\
\hline & Total & 135 \\
\hline
\end{tabular}

Sumber: Data kepegawaian Pusat Keuangan kementrian pertahanan 2015

Instrumen pengumpulan data dalam penelitian ini dengan memberikan daftar pertanyaan dan kuesioner secara langsung yang disebarkan kepada responden, yaitu pegawai di Pusat Keuangan Kementerian Pertahanan yang telah memenuhi kriteria untuk mendapatkan jawaban atas pertanyaan yang diajukanSkala yang digunakan dalam peneliatian ini adalah skala Likert. Dengan interval penelitian untuk setiap jawaban responden sebagai berikut:

1 : Sangat Tidak Setuju (STS) / Sangat Rendah / Sangat Buruk

2 : Tidak Setuju (TS) / Rendah / Buruk

$3: \operatorname{Netral}(\mathrm{N}) /$ Cukup

4 : Setuju (S) / Tinggi / Baik

\section{5 : Sangat Setuju (SS) / Sangat Tinggi / Sangat Baik}

Hasil uji validitas menunjukkan bahwa dari setiap indikator memiliki koefisien korelasi dengan validitas tertinggi 0,978 dan koefisien korelasi dengan validitas terendah 0, 922 . Hasil uji menunjukkan variabel yang diuji nilainnya $>0,3$ dengan signifikan $<0,05$ artinya data dapat dinyatakan valid dan dapat dilanjutkan ke tahap selanjutnya. 
Hasil uji reliabilitas menunjukkan bahwa nilai Croanbach Alpha tertinggi 0,980 dan terendah 0,954 , dengan begitu nilai lebih besar dari $>0,6$. sehingga seluruh variabel dikatakan realiabel, dan instrumen dapat dilanjutkan.

\section{PENGUMPULAN DATA}

Kuesioner teknik pengumpulan data dengan memberikan sejumlah pertanyaan tertulis secara terstruktur kepada responden penelitian berkaitan dengan berbagai variabel yang diteliti.

WawancaraPengumpulan data dengan mengadakan wawancara mendalam dengan beberapa responden untuk memperoleh data yang lebih akurat dan lengkap, menyangkut penjelasan lebih lanjut tentang kuesioner yang lebih diberikan.

\section{HASIL DAN PEMBAHASAN}

Karakteristik responden yang digunakan pada penelitian ini terdiri dari 5 (lima) karakteristik yaitu jenis kelamin, usia, pendidikan, pendapatan, masa kerja berikut ringkasan tentang karakteristik responden penelitian:

Tabel 5

Karakteristik Responden

\begin{tabular}{lccc}
\hline \multicolumn{1}{c}{ Keterangan } & \multicolumn{1}{c}{ Kategori } & Jumlah (orang) & Persen \\
\hline Jenis Kelamin & Wanita & 98 & 72,6 \\
Usia (tahun) & $31>-40$ & 87 & 64,4 \\
Pendidikan & SMA & 112 & 83 \\
Pendapatan & $4.100 .000>-5.000 .000$ & 55 & 40,8 \\
Masa Kerja & 21tahun>-30 tahun & 93 & 68,9 \\
& Jumlah & $\mathbf{1 3 5}$ & $\mathbf{1 0 0}$ \\
\hline
\end{tabular}

Sumber: Data diolah 2016

Berdasarkan presepsi responden dari setiap indikator dari variabel yang telah disebarkan. Diperoleh angka-angka yang dapat menunjukkan baik atau tidaknya variabel yang diteliti. Umar (2005) penilaian rata-rata skor dibagi 
menjadi lima kriteria. Karakteristik responden sebagian besar merupakan besar berjenis kelamin perempuan dikarenakan kegiatan operasional di Pusat keuangan merupakan banyak untuk keprluan administrasi keuangan. Oleh karena itu perempuan lebih teliti, berkonstrasi dalam mengurus urusan pekerjaan. Selanjutnya berdasarkan usia sebagian besar berusisa 30-40 orang dikarenakan banyak pegawai negeri sipil yang menjadi mayoritas pada Pusat Keuangan. Berdasarkan pendidikan paling besar pendidikan pegawai adalah SMA dikarenakan pada masa prekruitan pegawai mengkuti peraturan pemerintah yang lama bahwa pegawai boleh menjadi pegawai hanya dengan ijazah tamatan SMA. Berikutnya pendapatan pegawai yang sebagian besar 4.100.000>-5.000.000 adalah golongan VI. Dan karakteristik masa kerja paling dominan berusia 20 tahun>-30 tahun dikarenakan pegawai yang bekerja merupakan pegawai yang senang bekerja pada instansi kementerian serta mendapat SK pensiun. 


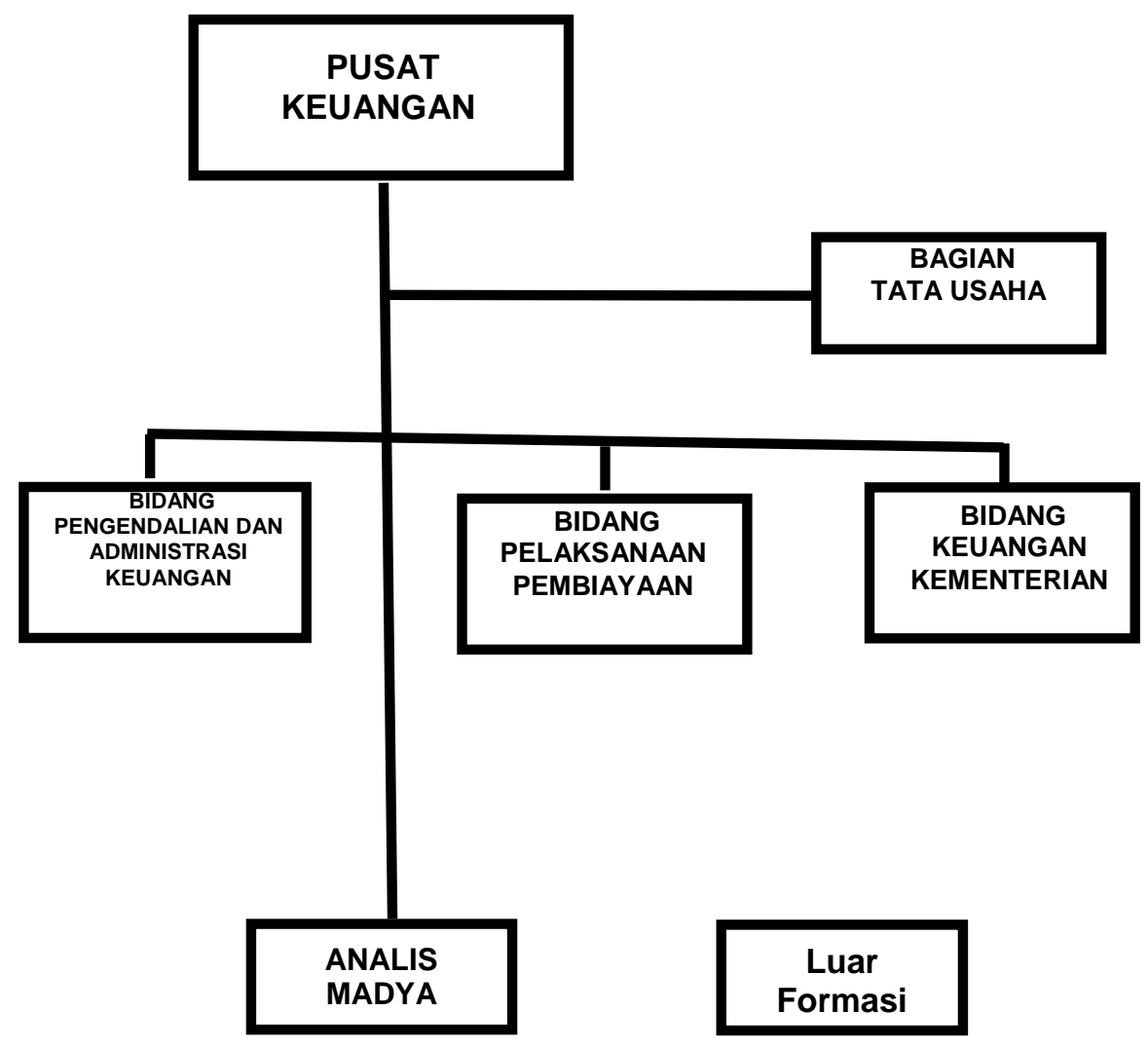

Gambar 2. Struktur Organisasi Pusat Keuangan

Sumber : Pusat Keuangan 2015

Pusat Keuangan Republik Indonesia merupakan departemen dibawah

Kementerian Pertahanan yang mencakup Inspektorat Jendral, Sekretariat Jendral,

Direktorat Jendral Strategi Pertahanan, Direktorat, Perencanaan Pertahanan,

Direktorat Potensi Pertahanan, Direktorat kekuatan Pertahanan, Badan Penelitian

Pengembangan, Badan Pendidikan dan Pelatihan, Pusat Data Informasi, dan Sarana Pertahanan, Badan Instalasi Strategi Nasional, Badan Pusat Komunikasi Publik, Pusat Rehabilitasi. Berdasarkan 13 departemen yang ada di bawah Kementerian Pertahanan, penelitian ini hanya menggunakan struktur organisasi Pusat Keuangan.

Keterlibatan Kerja 
Hasil penelitian menunjukkan bahwa keterlibatan kerja pegawai pada Pusat Keuangan Kementerian pertahanan sangat tinggi, ini dilihat dari dengan rata-rata variabel sebesar 4,34. Dengan rata-rata tertinggi indikator terlibat fisik dalam pekerjaan sebesar 4,45 dan indikator terendah terlibat aktif dalam tugas sebesar 4,19. Maka dapat disimpulkan keterlbatan kerja di pusat keuangan tinggi meski ada beberapa yang harus ditingkatkan

Komitmen Organisasional

Hasil penelitian menunjukkan bahwa komitmen organisasional pegawai pada Pusat Keuangan Kementerian pertahanan tinggi, ini dilihat dari dengan ratarata variabel sebesar 4,01. Dengan rata-rata tertinggi indikator komitmen berkelanjutan sebesar 4,08 dan komitmen normatif sebesar 4,00 serta dibawah rata-rata komitmen afektif sebesar 3,95. Maka dapat disimpulkan komitmen organisasional di pusat keuangan tinggi meski ada beberapa yang harus ditingkatkan.

\section{Kinerja Pegawai}

Hasil penelitian menunjukkan bahwa kinerja pegawai pada Pusat Keuangan Kementerian pertahanan baik, ini dilihat dari dengan rata-rata variabel sebesar 3,88. Dengan rata-rata tertinggi indikator kinerja hasil sebesar 4,04 dan dibawah rata-rata dimensi perilaku sebesar 3,95. Maka dapat disimpulkan kinerja pegawai di pusat keuangan baik meski ada beberapa yang harus ditingkatkan. 


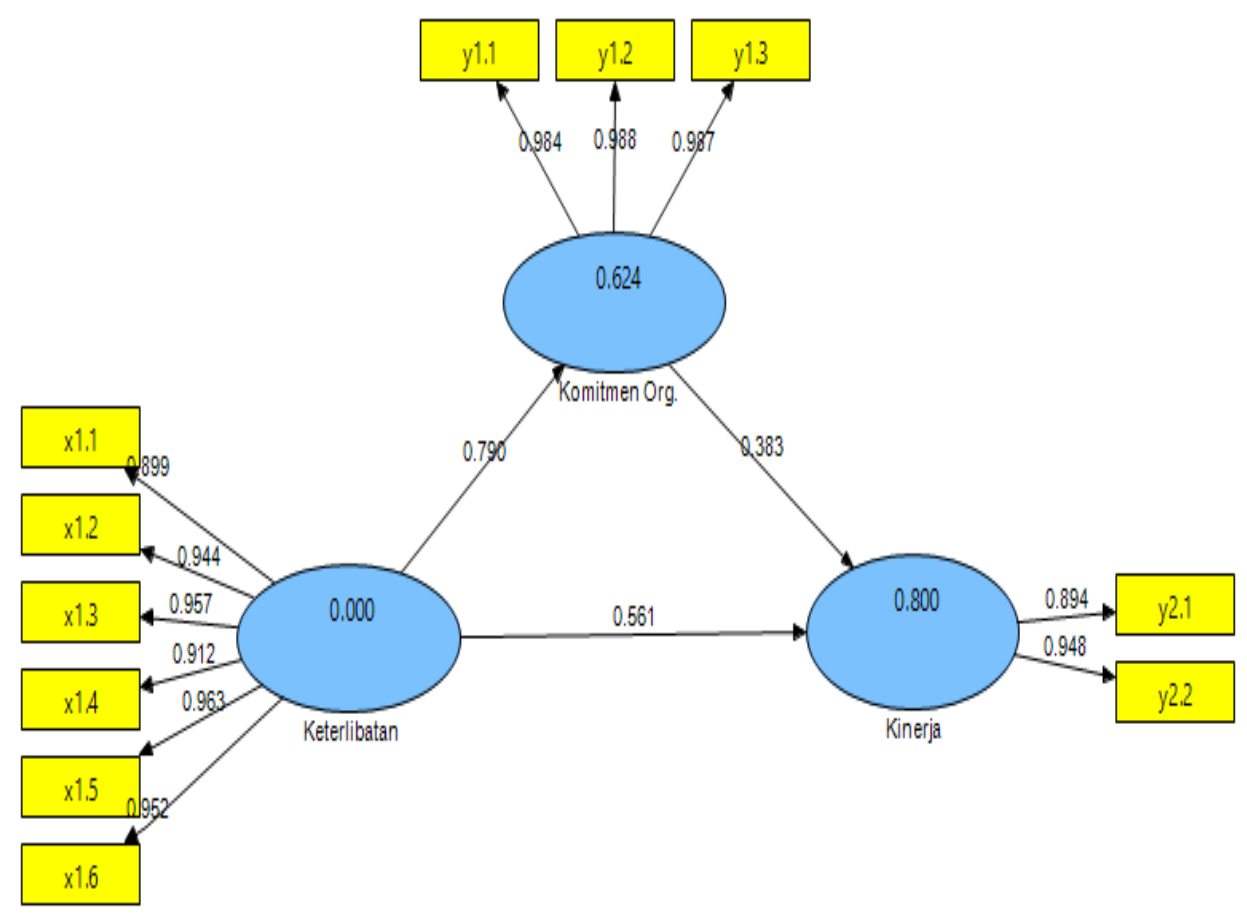

Gambar 3. Model Persamaan Struktural

Sumber : Data statistik diolah, 2016

Tabel 6

Composite Reliability

\begin{tabular}{lc}
\hline \multicolumn{1}{c}{ Variabel } & Composite Reliability \\
\hline Keterlibatan Kerja & 0.978 \\
Komitmen Organisasional & 0.991 \\
Kinerja & 0.919 \\
\hline
\end{tabular}

Sumber : Data statistik diolah, 2016

Penjelasan Tabel 4 dilihat nilai composite reliability setiap variabel memiliki nilai di atas 0,7 oleh karena itu dapat diintepretasikan sebagai variabel laten di penelitian ini telah reliabel sehingga dapat dilakukan pengujian selanjutnya. 
Tabel 7

Nilai R-square $\left(\mathbf{R}^{2}\right)$

\begin{tabular}{cc}
\hline Variabel & R Square \\
\hline Keterlibatan Kerja & \\
Komitmen Organisasional & 0.800 \\
Kinerja & 0.624 \\
\hline
\end{tabular}

Sumber : Data statistik diolah, 2016

Hasil dari Tabel 5.10 dapat dihitung nilai predictive-relevance $\left(\mathrm{Q}^{2}\right)$ yaitu : 1-(1-0,64) $\mathrm{x}(1-0,389)=(1-0,36) \times(1-0,611)=0,22-1=0,78$ Sedangkan keterlibatan kerja dengan komitmen organisasional sebesar $8,1 \%$

\section{Tabel 8}

Perhitungan VAF

\begin{tabular}{|c|c|c|}
\hline & Hubungan Variabel & Koefisien \\
\hline \multirow[t]{3}{*}{ Pengaruh Langsung } & $\begin{array}{l}\text { Keterlibatan Kerja -> Komitmen Organisasional } \\
(\beta 1)\end{array}$ & 0,790 \\
\hline & Komitmen Organisasional -> Kinerja $(\beta 2)$ & 0,383 \\
\hline & Keterlibatan Kerja -> Kinerja $(\beta 3)$ & 0,561 \\
\hline Pengaruh Tidak Langsung & $\beta 1 . \beta 2=0.790 \times 0.383$ & 0,302 \\
\hline Pengaruh Total & $\begin{array}{l}\text { Pengaruh Langsung }+ \text { Pengaruh Tidak Langsung }= \\
0.302+0.561\end{array}$ & 0,869 \\
\hline VAF & Pengaruh Langsung : Pengaruh Total $(0.302 / 0.863)$ & 0,420 \\
\hline
\end{tabular}

Sumber : Data statistik diolah, 2016

Hasil uji VAF pada Tabel 5.13 disimpulkan bahwa komitmen organisasional sebagai mediasi dengan nilai 0,350 (35\%). Hasil ini menujukkan bahwa variabel komitmen organisasional memiliki pengaruh pemediasi secara parsial (partial mediation) terhadap keterlibatan kerja dan kinerja, sehingga hipotesis yang menyatakan bahwa komitmen organisasi berperan sebagai pemediasi terhadap hubungan keterlibatan kerja dan kinerja pada Pusat Keuangan Kementerian Pertahanan diterima. 
Hasil pengujian hipotesis keterlibatan kerja terhadap komitmen organisasional. Hasil uji hipotesis menunjukkan adanya pengaruh positif dan signifikan. Hal ini dijelaskan bahwa semakin sering pegawai dilibatkan dalam suatu pekerjaan maka tingkat komitmen dalam organisasi akan semakin besar. Artinya semakin tinggi mengutamakan urusan pekerjaan, penting bagi haga diri, terlibat fisik dalam pekerjaan, dan pemberian motivasi, maka keterlibatan kerja di Instansi Pemerintahan akan meningkat. Hasil ini diperkuat penelitian yang dilakukan oleh Brown (2009), Lambert (2011), Agheli (2015), Khanam (2015), Rizwan (2015). Yang menyatakan bahwa keterlibatan kerja mempunyai pengaruh positif dan signifikan terhadap komitmen organisasional.

Hasil pengujian hipotesis keterlibatan kerja terhadap kinerja. Hasil uji hipotesis menunjukkan adanya pengaruh positif dan signifikan. Hal ini dijelaskan bahwa semakin tinggi pegawai yang dilibatkan dalam suatu pekerjaan maka tingkat kinerja pegawai akan meningkat. Artinya semakin tinggi mengutamakan urusan pekerjaan, penting bagi haga diri, terlibat fisik dalam pekerjaan, dan pemberian motivasi maka, keterlibatan kerja di Instansi Pemerintahan akan meningkat. Hasil ini diperkuat penelitian yang dilakukan oleh Ching (2015), Hackett (2010), Jayarathna (2011), Aisha (2014), Rizwan (2011). Yang menyatakan bahwa keterlibatan kerja mempunyai pengaruh positif dan signifikan terhadap kinerja.

Hasil pengujian hipotesis komitmen organisasional terhadap kinerja. Hasil uji hipotesis menunjukkan bahwa adanya pengaruh positif dan signifikan. Hal ini dijelaskan bahwa semakin tinggi pegawai berkomitmen kepada organisasi 
maka kinerja akan meningkat. Artinya semakin tinggi bekerja merupakan kebutuhan dan keinginan, berat meninggalkan pekerjaan, terganggu bila meninggalkan pekerjaan, sedikit pilihan untuk meninggalkan pekerjaan, maka komitmen organisasional di Instansi Pemerintahan akan mempengaruhi kinerja pegawai. Hasil ini diperkuat penelitian yang dilakukan oleh Maxwell (2009), Martin (2010), Memari (2013), Anan (2015), Preeti (2014). komitmen organisasional berpengaruh secara signifikan dan positif terhadap kinerja.

Hasil pengujian hipotesis peran mediasi komitmen organisasional terhadap keterlibatan kerja dan kinerja adanya pengaruh secara parsial. Hal ini dapat dijelaskan bahwa komitmen organisasi tidak berpengaruh langsung terhadap keterlibatan dan kinerja pegawai di Pusat Keuangan. Artinya semakin tinggi selesaikan, tanggung jawab, target dan waktu maka kinerja pegawai di Instansi Pemerintahan akan meningkat. Hasil ini diperkuat penelitian yang dilakukan oleh Chungtai (2008), Armanu (2015), Akram (2014), Kenny (1986), Ekmekçi (2011).

\section{IMPLIKASI PENELITIAN}

Secara teoritis hasil penelitian yang dilakukan menujukkan bahwa presepsi pegawai atas keterlibatan kerja, komitmen organisasional dan kinerja dipresepsikan baik oleh pegawai Pusat Keuangan Kementerian Pertahanan. Hasil penelitian ini mendukung penelitian-penelitian sebelumnya, terutama yang berkaitan dengan keterlibatan kerja, komitmen organisasional dan kinerja. Dengan kata lain penelitian dapat membuktikan bahwa komitmen organisasional berperan sebagai pemediasi terhadap hubungan antara keterlibatan kerja dan kinerja. Ini 
berarti bahwa untuk meningkatkan kinerja pegawai Kepala Pusat Keuangan harus memperhatikan secara sungguh-sungguh dalam keterlibatan kerja agar komitmen organisasional pegawai dapat meningkat.

Secara praktis dari hasil penelitian ini digunakan sebagai masukan bagi kepala Pusat Keuangan dalam membenahi diri sehubungan dengan keterlibatan kerja dan komitmen organisasional, agar dapat meningkatkan kinerja pada pegawai di Pusat Keuangan.

Keterbatasan dalam penelitian ini belum mengembangkan penelitian pada instansi pemerintahan yang berbeda dan dengan ruang lingkup di instansi pemerintahan yang berbeda dengan di sektor swasta, dengan hanya meneliti 2 variabel yang mempengaruhi kinerja yaitu keterlibatan kerja, dan komitmen organisasional. Objek penelitian yang dilakukan di Kementerian Pertahanan, menggunakan teknik analisis data SEM PLS dengan menggunakan uji mediasi VAF dan lokasi penelitian yang dilakukan di Jakarta, sehingga hasil temuan dalam penelitian ini dapat dijadikan pertimbangan dalam meningkatkan kinerja.

\section{SIMPULAN DAN SARAN}

Berdasarkan hasil pembahasan diatas, maka terdapat kesimpulan yaitu:

1). Keterlibatan kerja berpengaruh positif dan signifikan terhadap komitmen organisasional. Hal ini dapat dinyatakan bahwa semakin tinggi pegawai dilibatkan dalam suatu pekerjaan maka komitmen organisasional akan meningkat. Begitu pula sebaliknya semakin rendahnya pegawai yang dilibatkan dalam suatu pekerjaan maka komitmen organisasi akan menurun. 2). Keterlibatan kerja 
berpengaruh positif dan signifikan terhadap kinerja. Hal ini dapat dinyatakan jika semakin tinggi pegawai yang dilibatkan dalam suatu pekerjaan maka kinerja akan meningkat. Begitu pula sebaliknya semakin rendahnya pegawai yang dilibatkan dalam suatu pekerjaan maka kinerja akan menurun.3). Komitmen organisasional berpengaruh positif dan signifikan terhadap kinerja. Hal ini dapat dinyatakan bahwa semakin tinggi pegawai yang berkomitmen dalam suatu organisasi maka kinerja akan meningkat. Begitu pula sebaliknya semakin rendah pegawai yang berkomitmen dalam organisasi maka kinerja akan menurun. 4). Komitmen organisasional berperan sebagai pemediasi mempunyai pengaruh secara parsial terhadap hubungan antara keterlibatan kerja dan kinerja.

Berdasarkan kesimpulan terdapat saran yang dapat digunakan sebagai pertimbangan dalam menentukan kebijakan dimasa mendatang antara lain: 1). Bagi Pusat Keuangan Kementerian Pertahanan hal-hal yang perlu diperhatikan dalam meningkatkan keterlibatan pegawai di dalam suatu pekerjaan yaitu lebih sering melibatkan pegawai dalam setiap kegiatan yang pada akhirnya akan mencapai keberhasilan dalam setiap pekerjaan. 2). Bagi Pusat Keuangan Kementerian Pertahanan hal-hal yang perlu diperhatikan dalam meningkatkan komitmen organisasional, seharusnya kepala Instansi harus memperhatikan dilihat dari sisi dimensi komitmen afektif seperti: terikat emosional pada pekerjaan dan rasa kuat terhadap pekerjaan. Dimensi komitmen berkelanjutan: bekerja merupakan kebutuhan dan keinginan. Dan Dimensi komitmen normatif: tidak akan meninggalkan jika tawaran pekerjaan lain. 3). Bagi Pusat Keuangan Kementerian Pertahanan hal-hal yang perlu diperhatikan dalam meningkatkan 
kinerja pegawai, seharusnya kepala Instansi Pemerintah harus memperhatikan dilihat dari sisi dimensi kinerja perilaku: keputusan tanpa perintah, dan melakukan kecerobohan. Jika 2 hal tersebut dapat ditingkatkan, maka kinerja pegawai akan meningkat. 4). Bagi penelitian yang akan datang agar mempertimbangkan untuk mengganti objek penelitian seperti: industry swasta, mengganti teknik analisis mediasi dengan menggunakan metode uji sobel, serta menambah variabel yang terkait dengan penelitian ini yaitu: loyalitas, kepemimpinan, budaya organisasi, dan kompensasi.

\section{REFERENSI}

A.A. Anwar Prabu Mangkunegara. 2009. Manajemen Sumber Daya Manusia. Bandung: PT. Remaja Rosdakarya.

Aditya, Jajang. 2014. Pengaruh Komitmen Organisasional Terhadap Kinerja Karyawan Pada PT. Bukit Makmur Mandiri Utama Site Kideco Jaya Agung Batu Kajang Kabupaten Paser. Jurnal Ilmu Administrasi Bisnis. Vol. 2. No. 4. Pp: 833-845

Agheli, Reza Khadem. 2015. Impact Job involvement on turnover via organizational commitment and job satisfaction case study: Guilan medical staff. Journal of Scientific Research and Development. Vol. 2. No. 7. Pp: 35-39

Ahmad, Saufi, Roselina. 2013. Quality of Work Life on Employees Job Involvement and Affective Commitment between the Public and Private Sector in Malaysia. Journal Asian Social Science. Vol. 9. No. 7. P: 276

Aisha, Akbar. 2014. Job Involvement-Predictor of Job Satisfaction and Job Performance-Evidence from Pakistan University of Haripur Pakistan. World Applied Sciences Journal 30. Vol. 8. No. 2. P: 11

Aisha, Khanam. 2015.Organizational Commitment Of Employees In Relation To JobInvolvement And Job Satisfaction. International Journal in Management and Social ScienceVol. 3. No. 1. P:232

Altindag, Erkut. 2014. Organizational Ethics and Climate, Organizational Commitment in Job Performance at Health Institutions in Turkey. Journal 
of Business and Social Sciences. Vol. 3. No. 6. Pp: 44-60

Amir Ali and Chughtai. 2010. "Impact of Job Involvement on In-Role Job Performance and Organizational Citizenship Behaviour. Copyright (C) 2010. All Rights Rights Reserved 169Vol. 10. No. 2. P: 35

Anan, Hakim. 2015. Effect of Organizational Culture, Organizational Commitment toPerformance: Study In Hospital Of District South Konawe Of Southeast Sulawesi. The International Journal Of Engineering And Science. Vol. 3. No. 5. P: 39

Armanu. 2015. Pengaruh Keterlibatan Karyawan Gaya Kepemimpinan Dan Komitmen Organisasional Dalam Meningkatkan Kinerja Karyawan Studi Pada BRI Cabang Probolinggo. Jurnal ekonomi bisnis. Vol. 13. No. 3. P: 335

Baron, R. M., and Kenny, D. A. 1986. The moderator-mediator variable distinction in social psychological research: Conceptual, strategic, and statistical considerations. Journal of Personality and Social Psychology, Vol. 6. Pp: 1173-1182.

Ching-Sheue FU. 2015. The Effect of Emotional Labor on Job Involvement in Preschool Teachers: Verifying the Mediating Effect of Psychological Capital. The TurkishOnline Journal of Educational Technology. Vol. 14. No. 3. P: 146

Ekmekci, Asli, Kucukaslan. 2011. A study on involvement and commitment of employees in Turkey. Journal of Public Administration and Policy Research. Vol. 3. No. 3. Pp: 68-73.

Ghozali, Iman. 2009. Aplikasi Analisis Multi Variat dengan Program SPSS. Badan Penerbit Universitas Diponegoro. Semarang. P: 43

Goos, Lisa. M., and Irwin Silverman. 2002. Sex related factors in the perception of threatening facial expression. Journal of Nonverbal Behavior. Vol. 26. No. 2. Pp: 27-41.

Griffin. 2004. Komitmen Organisasi, Terjemahan, Jakarta: Erlangga.

Islam, T., Khan, S. U. R., Ahmed, U. N. U., and Ahmed, I. 2012. Does organisationalcommitment enhance the relationship between job involvement and in-role performance?. Journal of Human Resource Management. Vol. 1. No. 9. P: 460

Istijanto. 2005. Riset Sumber Daya Manusia. Jakarta : PT. Gramedia Pustaka umum 
Jackson, Schuler, Werner. 2011. Pengelolaan Sumber Daya Manusia 2. edisi kesepuluh. terjemahan. Jakarta : Salemba Empat.

Kemelgor, B. H. 2010. A Comparative Analysis of Corporate Entrepreneurial Orientation between Selected Firms in the Netherlands and the U.S.A. Journal Entrepreneurship and Regional Development. Vol. 14. No. 2. Pp: 67-87.

Khan, Tariq, Iqbal, Farooq, Ahmed, Jam, Aisha, Akbar, Muhammad, Bashir, Khan and Syed, Tahir-Hijazi. 2011. Job Involvement as Predictor of Employee Commitment: Evidence from Pakistan. International Journal of Business and Management. Vol.6. No. 4. Pp: 252-262

Kurniawan, Albert. 2015. Pengaruh Komitmen Organisasi Terhadap Organizational Citizenship Behavior (OCB) PT Sumber Bakti Bandung. Jurnal Manajemen. Vol. 15. No.1. P: 9

Mathis dan Jackson. 2011. Manajemen Sumber Daya Manusia. PT Salemba Emban Patria. Jakarta.

Maslow, Abraham. 2009. Motivasi dan Kepribadian. Jakarta : Midas Surya Grafindo.

Mahdieh, Omid. 2013. The impact of Organizational Commitment on Employees Job Performance. A study of Meli bank. Journal Of Contamporary Research In Business. Vol. 5. No. 5. P: 169

Mehwish, Akram. 2014. Mediation Role of Organizational Commitment in the Relationships of Organizational Politics and Job Involvement and Employee Performance. International Journal of Academic Research in Economics and Management Sciences. Vol. 3. No. 6. P: 226

Memari, N., Mahdieh, O and Marnani, A. B. 2013. The impact of organizational commitment on employees job performance. Interdisciplinary journal of contemporary research in business. Vol. 5. No. 5. Pp: 164-171

Nazish, Ayesha. 2015. Relationship Between Organizational Commitment, Employee Engagment And Career Satisfaction: A Case Of University Of Gujrat. Journal of Business and Social Sciences. Vol. 3. No. 11. Pp: 172183

Qaiser, Rizwan. 2015. Relationship Between JOB Performance, JOBInvolvement and Career Salience of Employees in Education Sector of Pakistan.American Journal of Educational Science. Vol. 1. No. 2. P: 19-22

Rizwan, Muhammad. 2011. Relationship of Job involvement with Employee 
Performance: Moderating role of Attitude. European Journal of Business and Management. Vol 3. No. 8. P: 283

Robbins. Stephen, P., Coulter. Mary. 2012. Management. Eleventh Edition. Jakarta: England.

Rostami, Majid. 2015. Job Involvement and Organizational Commitment of Employees of Prehospital Emergency Medical System Nurs Midwifery Journal. Vol. 4. No: 4. P: 306

Saxena, S. 2015. Impact of Job Involvement and Organizational Commitment on Organizational Citizenship Behavior.Internationat Journal Management Business. Vol. 4. No. 1. P: 30

Sedarmayanti. 2011. Manajemen Sumber Daya Manusia, Reformasi Birokrasi dan Manajemen Pegawai Negeri Sipil. cetakan kelima. Bandung : PT Refika Aditama.

Sendow, Greis. 2015. Beban Kerja, OrganizationalL Citizenship Behavior, Dan Keterlibatan Kerja Pengaruhnya Terhadap Kinerja Karyawan PT. PLN (PERSERO) Wilayah Suluttenggo Area Manado. jurnal ekonomi dan pembangunan.Vol. 3. No. 2. Pp: 71

Sethi, Ardhana. 2016. A study of job involvement among senior secondary school teachers. International Journal of Applied Research. Vol. 2. No. 2. Pp: 205209

S.M.D.Y. Jayarathna. 2014. The effect of Employee Work Related Attitudes on Employee Job Performance: A Study of Tertiary and Vocational Education Sector in Sri Lanka. IOSR Journal of Business and Management (IOSRJBM). Volume. 16. No. 4. Pp: 74-83

Soekidjan. 2009. Manjaemen Sumber Daya Manusia. Jakarta. Bumi Aksara

Srivastava, Preeti. 2014. The Effect Of Organizational Commitment, And Job Satisfaction, On Employees Job Performance. International Journal of Art and Humanity Science. Vol. 1. No. 2. P: 23

Wibowo. 2010. Manajemen Kinerja. Edisi Ketiga. Penerbit Rajawali Pers. Jakarta.

Zare, Bahram Abadi M, Darre I, Azhdari, G. 2012. The relationship between job involvement, responsibility and emotional analysis withjob satisfaction, Journal of Counseling and Psychotherapy. Vol. 3. No. 4. Pp: 5-24

Ziauddin. 2010. The Impacts of organizational commitment on employee job 
Sebastianus Alexander Septiadi, Desak Ketut Sintaasih, dan I Made Artha Wibawa. Pengaruh...

performance study on public sector employee of oil and gas in Pakistan.EuropianJournal of Social Sciences.Vol. 15. No. 3. P: 296 